\title{
In Vitro Effect of Crude Extract from Traganum Nudatum on Glucose-Uptake in Liver Slices Isolated from Westar Rats
}

\author{
Type of article: Conference abstract \\ F. Mouderas, D. Mezouar, N. H. Benahmed, F.B. Lahfa \\ Faculté des Sciences de la Terre et de l'Univers, Sciences de la Nature et de la Vie Département de \\ Biologie, Université Abou Bekr Belkaid, Tlemcen, Algeria \\ Laboratoire: Antibiotiques, Antifongiques, Physico-Chimie, Synthèse et Activités Biologiques, \\ Université Abou Bekr Belkaid, Tlemcen, Algeria \\ Corresponding Author: faizamoud@gmail.com
}

\begin{abstract}
Background: Diabetes mellitus is a metabolic disorder characterized by chronic hyperglycemia resulting from defects in insulin secretion, insulin action, or both. There are many classes of drugs used for treatment, and these include insulin sensitizers, insulin secretagogues, and agents that delay the absorption of carbohydrates from the bowel. This study intends to investigate the effect of crude extract from a plant from South Algeria Traganum nudatum (Chenopodiaceae) on glucose uptake in liver slices isolated from Wistar rats.

Methods: The liver slices were incubated for $90 \mathrm{~min}$ at $37^{\circ}$ in normoglycaemic $(1 \mathrm{~g} / \mathrm{l}$ of glucose) and hyperglycaemic (3g/l of glucose) KRBA Krebs Ringer Bicarbonate Albumin $4 \%$ media using 24 well-polyethylene plates. In each, well different concentrations of insulin $(10,50$ and $100 \mu \mathrm{U} / \mathrm{ml})$ and hydromethanolic crude extract $(100,200$ and $500 \mu \mathrm{g} / \mathrm{ml})$ were added. After every 30 minutes, aliquots of the culture media were assayed for the determination of glucose left.

Results: Tests showed that the glucose left after 90 minutes in the media which contained insulin at $100 \mu \mathrm{g} / \mathrm{ml}$ was the lowest $(0.44$ and 1.41$) \mathrm{g} / \mathrm{l}$ in the normo and hyperglycaemic media respectively, which reflect that insulin at this concentration was the most effective on the stimulation of glucose uptake. The extract had the highest effect at $500 \mu \mathrm{g} / \mathrm{ml}$, the concentrations of glucose left after 90 minutes of incubation were found to be $(0.38$ and 1.31$) \mathrm{g} / \mathrm{l}$ in the normoglycaemic and hyperglycaemic media respectively.

Conclusion: From the obtained results, it can be concluded that our extract seems to have an insulin-like effect on glucose uptake in liver slices isolated from Wistar rats.

Keywords: Diabetes Mellitus, Insulin, Glucose Uptake, Liver Slices, Traganum Nudatum
\end{abstract}

\section{Conflict of interest statement}

This article is a conference abstract presented at the International Congress on Health Sciences and Medical Technologies, Tlemcen Algeria 5-7 December 2019, ICHSMT'19.

\section{Authors' biography}

No Biography. 
Medical Technologies Journal, Volume: 4, Issue: 2, April-June 2020, Pages:550-551. Doi :

https://doi.org/10.26415/2572-004X-volxissxp550-551

\section{References}

No references 